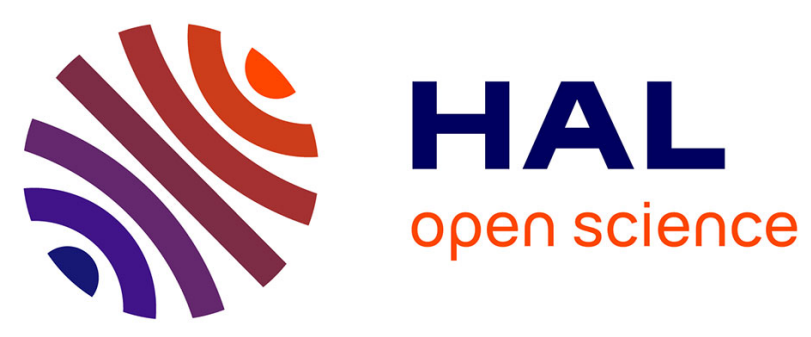

\title{
Cleaners and airway diseases
}

Orianne Dumas

\section{To cite this version:}

Orianne Dumas. Cleaners and airway diseases. Current Opinion in Allergy and Clinical Immunology, 2021, 21 (2), pp.101-109. 10.1097/ACI.0000000000000710 . inserm-03166925

\section{HAL Id: inserm-03166925 https://www.hal.inserm.fr/inserm-03166925}

Submitted on 11 Mar 2021

HAL is a multi-disciplinary open access archive for the deposit and dissemination of scientific research documents, whether they are published or not. The documents may come from teaching and research institutions in France or abroad, or from public or private research centers.
L'archive ouverte pluridisciplinaire HAL, est destinée au dépôt et à la diffusion de documents scientifiques de niveau recherche, publiés ou non, émanant des établissements d'enseignement et de recherche français ou étrangers, des laboratoires publics ou privés. 


\section{Cleaners and airway diseases}

Orianne Dumas

Université Paris-Saclay, UVSQ, Univ. Paris-Sud, Inserm, Équipe d'Épidémiologie respiratoire intégrative, CESP, 94807, Villejuif, France

\section{Correspondence}

Orianne Dumas

Inserm, CESP, Équipe d'Épidémiologie respiratoire integrative

16, avenue Paul Vaillant Couturier

94807 Villejuif cedex

France

e-mail: orianne.dumas@inserm.fr

Phone: (33) 145595357

Acknowledgements

None

Funding

Anses PNREST 2020/1/047 - CONETRE

Conflict of interest

None

Word count: 2854 


\section{Abstract}

Purpose of review: Evidence for adverse respiratory effects of occupational exposure to disinfectants and cleaning products (DCPs) has grown in the last two decades. The relationship between DCPs and asthma is well-documented, but questions remain regarding specific causal agents. Beyond asthma, associations between DCPs and COPD or chronic rhinitis are plausible and have been examined recently. The purpose of this review is to summarize recent advances on the effect of occupational exposure to DCP and chronic airway diseases.

Recent findings: Recent epidemiological studies have often focused on healthcare workers and are characterized by efforts to improve assessment of exposure to specific DCPs. Despite increasing knowledge on the effect of DCPs on asthma, the burden of work-related asthma caused by DCPs has not decreased in the past decade, emphasizing the need to strengthen prevention efforts. Novel data suggest an association between occupational exposure to DCPs and other chronic airway diseases, such as rhinitis, COPD and poor lung function.

Summary: Epidemiological and experimental data showed that many chemicals contained in DCPs are likely to cause airway damages, indicating that prevention strategies should target multiple products. Further research is needed to evaluate the impact of DCPs exposure on occupational airway diseases beyond asthma.

Keywords: disinfectants, cleaning products, occupational airway diseases, asthma, COPD

Abstract word count: 198 


\section{Introduction}

Evidence for adverse respiratory health effects of exposure to disinfectants and cleaning products (DCPs) has grown in the last two decades [1,2]. Due to their widespread use both in the general population [3,4] and at the workplace [5], DCPs raise important public health concerns. In the context of the COVID-19 pandemic, the use of DCPs has further increased in healthcare settings, as well as in other public- and work- places and in individual homes [6]. Some workers experience particularly high level of exposure to DCPs, which is a major cause of work-related asthma (WRA) [5,7]. Because cleaning and disinfection are crucial in some environments, such as healthcare, to prevent the spread of infections, it remains a challenging issue for prevention of occupational airway diseases [8].

Although the relationship between occupational exposure to DCPs and asthma is now welldocumented, as reviewed in 2017 by Folletti et al. [5], research in this field is still very active, as questions remain in particular regarding specific causal agents. Beyond asthma, it is plausible that inhalation of irritants and sensitizers from DCPs may be associated with other chronic respiratory diseases, such as chronic obstructive pulmonary disease (COPD) or chronic rhinitis $[9,10]$, and research work on these novel hypotheses has emerged in the past few years. The purpose of this review is to summarize and discuss recent advances on the effect of occupational exposure to DCPs and chronic airway diseases, including asthma, rhinitis and COPD.

\section{Asthma}

Evidence for a relationship between occupational exposure to DCPs and asthma emerged in the early 2000's, with consistent findings from work-related asthma (WRA) surveillance schemes, reporting elevated proportions of asthma cases in cleaning and healthcare occupations, and population- or workforce-based epidemiological studies examining associations between exposure to DCPs and asthma [11]. Today, both types of studies remain useful as they provide complementary data to better characterize the relationship between DCPs and asthma, and up-to-date information to evaluate the related public health burden [12]. This section summarizes studies published since the last review by Folletti et al. [5].

\section{Work-related asthma surveillance networks and case series}

Recent data from WRA surveillance networks or case series in the UK and North America showed that $8-12 \%$ of all WRA cases were attributed to cleaning products $[7,13-15]$. Consistent with previous reports [11], most cases were from the healthcare and cleaning industries $[7,13,14]$. However, a variety of industries were reported, such as education and 
leisure (including swimming-pool employees), reflecting the common use of DCPs in many workplaces. Regarding causal agents, the most frequent in The Health and Occupation Research (THOR) network in the UK were aldehydes, with a tendency to decrease over time, and chlorine, which maintained its contribution over the reporting period [13]. In the US, the most frequently reported causes were cleaning materials or unspecified general purpose cleaners, floor strippers or waxes, bleach, and disinfectant cleaners [7]. In a Canadian WRA case series, although the most frequent exposures included surfactants, alcohols, disinfectants and acids, workers were commonly exposed to multiple products including both potential sensitizers and irritants, and a specific causative agent was rarely identified [15].

In the US, cases identified by surveillance systems from 1998 to 2012 were compared to data collected from 1993 to 1997 [7]. No decrease in the proportion of cases attributed to cleaning products was observed between the two periods. Similarly, data from the THOR network showed that in contrast with a general declining trend in occupational asthma incidence between 1989 and 2017, no reduction in cases attributed to cleaning agents was observed [13]. These data suggest that despite the increased amount of data in the scientific literature on the relationship between DCPs and asthma in the last decades, no decrease is observed in the occurrence of cleaning-related WRA.

\section{Epidemiological studies}

Epidemiological studies on the association between occupational exposure to DCPs and asthma are summarized in Table 1. An increasing number of studies have been conducted among healthcare workers, who are particularly frequently exposed to DCPs, including high level disinfectants. Recent studies are also characterized by efforts to improve assessment of exposure to specific DCPs.

Several results have been published in the context of the Nurses' Health Study II, a prospective cohort study of 116429 US female nurses. A job-task-exposure matrix was designed in this population to evaluate exposures to specific DCPs [16]. A cross-sectional analysis first investigated the association between exposure to specific DCPs and asthma control among 4,102 nurses with asthma [17]. Using the job-task-exposure matrix, high levels of exposure to formaldehyde, glutaraldehyde, hypochlorite bleach, hydrogen peroxide and enzymatic cleaners were associated with poor asthma control; exposure to quaternary ammonium compounds and alcohol were not. A separate analysis examined the association between hand/arm hygiene tasks and asthma control, and suggested an adverse effect of products used for surgical hand/arm antisepsis [18]. A prospective analysis in the Nurses' Health Study II further examined the association of occupational exposure to DCPs with asthma incidence [19]. Exposure to DCPs was not associated with incident asthma. However, this analysis, conducted in a population of late career nurses (mean age: 55 years), was likely affected by a 
healthy worker effect. The Nurses' Health Study 3, a prospective cohort of early- to mid- career nurses in the US and Canada, offered an opportunity to limit this bias when investigating the association between occupational exposures and asthma. In a prospective analysis including 17,280 female nurses (mean age: 34 years), nurses who reported $>5$ years of use of high level disinfectants had increased risk of incident asthma (adjusted hazard ratio $[95 \% \mathrm{Cl}], 1.38$ [1.031.85]) [20]. No information was available on exposure to lower level disinfectants and common cleaning products.

In a cross-sectional study including 2030 healthcare workers in New York City, Caridi et al. [21] found that the task of cleaning surfaces was associated with increased risk of current asthma. Occupations with the highest risk of current asthma were environmental service workers and registered nurses. In the same population, Su et al. [22] identified health clusters based on 27 asthma symptom/care variables, and exposure clusters based on 14 products application during cleaning and disinfecting activities, separately by hierarchical clustering. This strategy aimed at addressing both asthma heterogeneity and the multiplicity of DCPs exposures when examining their association. Several exposure clusters, reflecting various combination of DCPs use, were associated with different asthma clusters. In particular, the exposure cluster "housekeeping/chlorine" was associated with "undiagnosed/untreated asthma" and "asthma attacks/exacerbations". "General cleaning/laboratory" was associated with "asthma attacks/exacerbations". "Disinfection products" was associated with "mild asthma symptoms" and "undiagnosed/untreated asthma".

Smaller cross-sectional studies conducted in various countries and settings reported overall similar results. In a survey of 347 workers employed at a veterans administration medical center in the US, several cleaning and disinfection tasks were associated with increased risk of current asthma, although results should be interpreted with caution as only unadjusted associations were presented [23]. In a study of 239 certified nurse aides in Texas [24], no significant association was observed between cleaning and disinfection tasks or products and bronchial hyperresponsivenness-related symptoms. However, this study of relatively small size may have lacked power to detect significant asssociations, despite elevated odds ratios for some exposures. In addition, nurse aides are more often employed outside hospital than other healthcare professions (e.g., registered nurses) and may thus have lower level of exposure to DCPs [21,25]. In a health hazard evaluation conducted by the National Institute for Occupational Safety and Health (NIOSH) in a US hospital including 163 workers, air samples were collected and analyzed for hydrogen peroxide, peracetic acid, and acetic acid [26,27]. Workers in the department with the highest air measurements had higher risk of current asthma compared with the US population. Lower and upper airway symptoms were examined in a subsample of workers $(n=50)$. No significant association between exposure and lower airway symptoms was reported [26]. In a cross-sectional study in New Zealand, cleaning workers 
$(n=425)$ had higher risk of current asthma than reference workers [28]. Finally, Weinmann et al. [29] examined the relationship between exposure to disinfectants and asthma among 356 German young adults working in health or cleaning services. They reported a three-fold increased risk of asthma after only twelve months of occupational exposure to disinfectants.

\section{Rhinitis and nasal symptoms}

In 2013, Siracusa et al. [30] reviewed agents and activities newly identified as potential causes of work-related rhinitis, with a focus on irritant-induced rhinitis. Healthcare and cleaning work, or DCPs, were among the most frequently reported activities or agents. Literature reviews on asthma and rhinitis in cleaners [10] and healthcare workers [31] also suggested that exposure to cleaning products was associated with rhinitis and nasal symptoms, although data remain limited. In a recent cross-sectional study of 16,099 adults in Norway, Clarhed et al. [32] examined the association between occupational exposures to several airbone irritants or sensitizers evaluated by questionnaire, and chronic rhinosinusitis defined based on selfreported symptoms of nasal blocakge or nasal discharge. Participants ever exposed to cleaning agents had signigicantly increased risk of chronic rhinosinusitis (adjusted odds ratio: 1.2, 95\% confidence intervall: 1.0-1.3). In the health hazard examination conducted by the $\mathrm{NIOSH}$ in a US hospital (described in the previous section), significantly increased risk of both acute and chronic nasal symptoms was found in workers with high exposure to a product containing hydrogen peroxide, peracetic acid, and acetic acid [26]. In a cross-sectional study of 543 healthcare workers in France, exposure to quaternary ammonium compounds was associated with work-related nasal symptoms [33].

\section{COPD and lung function}

Due to the irritant properties of many chemicals contained in DCPs, hypotheses regarding a potential impact of DCPs exposure on COPD and lung function have emerged in the past few years [34,35]. Studies conducted on this question since 2016 are summarized in Table 2.

In a large mortality study based on linkage of Belgian census, register and death certificate data, higher risk of COPD mortality was found in cleaners compared to non-manual workers [36]. In a population of 13,259 Hispanic adults in the US, occupational exposure to cleaning and disinfecting solutions was associated with increased risk of chronic bronchitis [37], consistently with earlier results from a population-based study in Northern Europe [35]. In the the UK Biobank, a first analysis including data from 228,614 adults showed that current employment as a cleaner was associated with increased risk of spirometry-defined COPD [38] A more recent analysis of the UK Biobank examining complete occupational history in a 
subsample of 94,551 participants found no association between ever working as a cleaner, or duration of cleaning employment, and COPD [39]. These seemingly contradictory results emphasize the need for a better assessment of occupational exposure to DCPs (e.g., through the use of job-exposure matrices) over the lifetime in large cohorts, to clarify exposure trajectories associated with COPD risk.

In a cross-sectional study of US working adults, the highest prevalence of self-reported COPD was found among healthcare support occupations [40]. In a prospective analysis of 73,262 US female nurses from the Nurses' Health Study II, occupational exposure to DCPs, evaluated by questionnaire and a job-task-exposure matrix, was significantly associated with an increased risk of developing COPD [9]. The association was observed among participants both with and without asthma. High-level exposure to several specific disinfectants (i.e. glutaraldehyde, bleach, hydrogen peroxide, alcohol, and quaternary ammonium compounds) was significantly associated with COPD incidence.

In a cross-sectional study in New-Zealand, cleaners had lower lung function (FEV $1, F V C$ ) than reference workers [28]. In a longitudinal analysis of 6,235 adults from the European Community Respiratory Health Survey, cleaning activities (both cleaning at home and working as a cleaner) were associated with accelerated $\mathrm{FEV}_{1}$ and FVC decline [41]. This result was observed in women only and independent of asthma. No association was observed between cleaning activities and $\mathrm{FEV}_{1} / \mathrm{FVC}$ decline or airway obstruction. However, there were only few cases of incident airway obstruction and this analysis had limited power [41,42]. In an older study in a large French cohort, an association between occupational exposure to detergents and lung function was also observed independently of asthma [43].

\section{Mechanisms}

Occupational asthma can be induced by allergic (sensitizer-induced) and nonallergic (irritantinduced) mechanisms, and both types of mechanisms have been described for DCPs, depending on the specific causal agent $[5,44]$. Similarly, occupational rhinitis can be classified as allergic or non-allergic [30]. Irritant-induced asthma or rhinitis can be caused by a single high level (accidental) exposure to irritants or by chronic, lower level ('daily-life') exposure to irritants $[30,45,46]$. Chronic exposure to inhaled irritants from DCPs may cause injury of the airway epithelium, oxidative stress and neutrophilic airway inflammation [47-49], which are also relevant to COPD pathogenesis.

Among all cleaning agents reported as likely causative agents of occupational asthma in THOR surveillance network, 15 low molecular weight organic compounds were identified [13]. According to a Quantitative Structure Activity Relationship (QSAR) model, 7 of these 15 agents had a respiratory sensitization potential. In a smaller subset of 80 patients with occupational 
asthma attributed to cleaning agents, sensitization mechanism was suggested by the clinician's evaluation in $84 \%$ of cases [14], but could be confirmed by specific inhalation challenges only in a small proportion. Among patients with occupational asthma from cleaning agents in Canada [15], 42\% had a diagnosis of irritant-induced asthma. However, irritantinduced asthma may be largely underestimated among occupational asthma cases reported by physicians [50], as for this type of asthma the causal agent cannot be identified with certainty in a specific worker [51]. Epidemiological studies examining specific asthma phenotypes such as allergic vs. non allergic asthma are generally consistent with a predominant role of irritant exposures and the hypothesis of nonallergic mechanisms for workplace exposure to most DCPs [52-54].

Mechanistic studies on respiratory effects of inhaled chemicals from DCPs have been reviewed by Clausen et al. [1], with a focus on ingredients from cleaning sprays. Although there is a limited number of inhalation studies in human, pulmonary effects have been reported after inhalation of several agents including chlorine, chloramine, acids, aldehydes and quaternary ammonium compounds [1]. Rodent models examining several quaternary ammonium compounds showed that inhalation of these chemicals caused pulmonary damage and neutrophilic inflammation, and suggested amplified effects when they were mixed with other chemicals such as ethylene glycol [1]. Chlorine exposure is also commonly used in experimental models examining effects of inhaled irritants on the airway $[44,48,55]$. Recent studies have focused on the airway epithelial barrier, which plays an important role in asthma, rhinitis and COPD $[48,55]$. Using a mice model of airway epithelial damage aiming at mimicing human accidental exposure to high level of an irritant agent followed by lower dose irritant exposure (as sometimes observed in irritant-induced asthma), Van Den Broucke et al. showed that airway exposure to hypochlorite resulted in airway hyperreactivity and pulmonary inflammation in mice with previously damaged epithelial barrier [48]. A study examining the effects of laundry detergents (which may contain both irritants and sensitizers) on human bronchial epithelial cells also supported a disruptive effect on the epithelial barrier function [56]. Injury of the epithelium caused by irritant exposure may increase epithelial permeability, potentially facilitating penetration of allergens [56,57]. In mice with pre-existing allergic lung inflammation, chlorine exposure has also been shown to contribute to potentiation of Th2 response [57], and to aggravate airway hyperresponsiveness and inflammation by activation of innate immune cells [58].

Oxidative stress has been suggested as one of the mechanisms for the impact of inhaled irritant cleaning products on the airway epithelium [44,59]. In accordance with this hypothesis, an Italian study of hospital cleaners reported that potential biomarkers of oxidative stress in exhaled breath condensate were higher in cleaners compared to control workers, while Fractional exhaled Nitric Oxide levels were similar in both groups [47]. 
Finally, a new interesting hypothesis regarding mechanisms of health effects of DCPs involves a role of the microbiome. DCPs, which aim at removing or inactivating microorganisms, are likely to influence indoor environmental microbiota, and possibly gut or airway microbiota, which may in turn impact respiratory health [2,60,61]. In a Canadian birth cohort, the use of disinfectants or eco-friendly products for home cleaning was associated with significant differences in infants' gut microbiota composition [60]. In adults, although DCPs have not been specifically examined, a few recent studies suggested that occupational exposures to chemicals [62], as well as ozone exposure [63], may alter the gut or airway microbiota.

\section{Conclusion}

The adverse effect of occupational exposure to DCPs in asthma on now well-established. However, recent data showed that the burden of WRA caused by DCPs exposure has not decreased in the past decade, emphasizing the need to strengthen prevention efforts $[7,42]$. Novel data suggest an association between occupational exposure to DCPs and other chronic airway diseases, such as rhinitis, COPD and poor lung function, and support the conduct of further studies. Epidemiological and experimental data show that many chemicals contained in DCPs are likely to cause airway damage, indicating that prevention strategies should target multiple products and may require the development and evaluation of "green chemistry" or non-chemical disinfection methods [8,64]. Improving local ventilation and use of adequate personal protective equiment has also been suggested [8]. Recent studies aiming at improving characterization of DCPs exposures $[1,65-70]$ represent a first step toward the development of exposure reduction strategies. 


\section{Key points:}

- The relationship between occupational exposure to disinfectants and cleaning products and asthma is well-documented, but questions remain regarding specific causal agents.

- Recent epidemiological studies have often focused on healthcare workers and are characterized by efforts to improve assessment of exposure to specific DCPs.

- The burden of work-related asthma caused by disinfectants and cleaning products has not decreased in the past decade, emphasizing the need to strengthen prevention efforts.

- Novel data suggest an association between occupational exposure to disinfectants and cleaning products and other chronic airway diseases, such as rhinitis, COPD and poor lung function, and support the conduct of further studies.

- Epidemiological and experimental data show that many chemicals contained in disinfectants and cleaning products are likely to cause airway damage, indicating that prevention strategies should target multiple products. 


\section{Bulleted references:}

** Clausen PA, Frederiksen M, Sejbæk CS, et al. Chemicals inhaled from spray cleaning and disinfection products and their respiratory effects. A comprehensive review. Int. J. Hyg. Environ. Health. 2020;229:113592.

This review focused on the respiratory effects associated with the use of cleaning spray (either at home or at work) provides a recent and comprehensive synthesis of results from epidemiological and clinical studies, toxicological studies of cleaning chemicals, as well as human and field exposure studies.

* Rosenman K, Reilly MJ, Pechter E, et al. Cleaning Products and Work-Related Asthma, 10 Year Update. J. Occup. Environ. Med. 2020;62:130-137.

This study provides updated data on the occurrence of work-related asthma associated with cleaning products from surveillance programs in five US states. Of all work-related asthma cases, $12 \%$ (1199) were related to cleaning products. This proportion was unchanged since the mid 1990's, emphasizing the need to strengthen prevention efforts.

** Dumas O, Varraso R, Boggs KM, et al. Association of Occupational Exposure to Disinfectants With Incidence of Chronic Obstructive Pulmonary Disease Among US Female Nurses. JAMA Netw. Open. 2019;2:e1913563.

This prospective cohort study of 73,262 US female nurses from the Nurses' Health Study II showed that occupational exposure to cleaning products and disinfectants was significantly associated with a $25 \%$ to $38 \%$ increased risk of developing chronic obstructive pulmonary disease, independent of asthma and smoking.

* Dumas O, Gaskins AJ, Boggs KM, et al. Occupational use of high-level disinfectants and asthma incidence in early to mid-career nurses: a prospective cohort study. Eur. Respir. J. 2019;54:OA3282.

[Note: this reference is currently reported as a conference abstract; the corresponding paper is currently in revision (minor revision). Reference will be changed upon acceptance]

This prospective study of 17,280 early to mid-career female nurses (mean age: 34 years), in the US and Canada, showed that occupational use of high level disinfectants among nurses was associated with significantly increased risk of developing asthma, adding longitudinal evidence to an association between occupational exposure to disinfectants and asthma.

* Su FC, Friesen MC, Humann M, et al. Clustering asthma symptoms and cleaning and disinfecting activities and evaluating their associations among healthcare workers. Int. J. Hyg. Environ. Health. 2019;222:873-883.

This cross-sectional study of 2030 healthcare workers in New York City used a novel approach based on hierarchical clustering to identify health and exposure clusters to address both asthma heterogeneity and the multiplicity of disinfectants and cleaning exposures when examining their association. Several exposure clusters, reflecting various combination of products use, were associated with different asthma clusters.

** Svanes $\varnothing$, Bertelsen RJ, Lygre S, et al. Cleaning at Home and at Work in Relation to Lung Function Decline and Airway Obstruction. Am J Respir Crit Care Med. 2018;197:1157-1163.

This longitudinal analysis of the ECRHS, based on 3 time points of follow-up over $\sim 20$ years and including 6,235 participants, showed for the first time that exposure to cleaning activities 
either at work or at home was associated with accelerated $\mathrm{FEV}_{1}$ and FVC decline. This result was observed in women only and independent of asthma. 


\section{References}

[1] Clausen PA, Frederiksen M, Sejbæk CS, et al. Chemicals inhaled from spray cleaning and disinfection products and their respiratory effects. A comprehensive review. Int. J. Hyg. Environ. Health. 2020;229:113592.

[2] Dumas O, Le Moual N. Damaging effects of household cleaning products on the lungs. Expert Rev. Respir. Med. 2020;14:1-4.

[3] Lemire $P$, Dumas $O$, Chanoine $S$, et al. Domestic exposure to irritant cleaning agents and asthma in women. Environ. Int. 2020;144:106017.

[4] Weinmann T, Gerlich J, Heinrich S, et al. Association of household cleaning agents and disinfectants with asthma in young German adults. Occup. Environ. Med. 2017;74:684-690.

[5] Folletti I, Siracusa A, Paolocci G. Update on asthma and cleaning agents. Curr. Opin. Allergy Clin. Immunol. 2017;17:90-95.

[6] Zheng G, Filippelli GM, Salamova A. Increased Indoor Exposure to Commonly Used Disinfectants during the COVID-19 Pandemic. Environ. Sci. Technol. Lett. 2020;7:760-765.

[7] Rosenman K, Reilly MJ, Pechter E, et al. Cleaning Products and Work-Related Asthma, 10 Year Update. J. Occup. Environ. Med. 2020;62:130-137.

[8] Tarlo SM, Arif AA, Delclos GL, et al. Opportunities and obstacles in translating evidence to policy in occupational asthma. Ann. Epidemiol. 2018;28:392-400.

[9] Dumas O, Varraso R, Boggs KM, et al. Association of Occupational Exposure to Disinfectants With Incidence of Chronic Obstructive Pulmonary Disease Among US Female Nurses. JAMA Netw. Open. 2019;2:e1913563.

[10] Folletti I, Zock JP, Moscato G, et al. Asthma and rhinitis in cleaning workers: A systematic review of epidemiological studies. J. Asthma. 2014;51:18-28.

[11] Zock JP, Vizcaya D, Le Moual N. Update on asthma and cleaners. Curr Opin Allergy Clin Immunol. 2010;10:114-120.

[12] Jaakkola MS, Jaakkola JJ. Assessment of public health impact of work-related asthma. BMC Med Res Methodol. 2012;12:22.

[13] Carder M, Seed MJ, Money A, et al. Occupational and work-related respiratory disease attributed to cleaning products. Occup. Environ. Med. 2019;76:530-536.

[14] Walters GI, Burge PS, Moore VC, et al. Cleaning agent occupational asthma in the West Midlands, UK: 2000-16. Occup. Med. (Lond). 2018;68:530-536.

[15] Li RWH, Lipszyc JC, Prasad S, et al. Work-related asthma from cleaning agents versus other agents. Occup. Med. (Chic. III). 2018;68:587-592.

[16] Quinot C, Dumas O, Henneberger PK, et al. Development of a job-task-exposure matrix to assess occupational exposure to disinfectants among US nurses. Occup Env. Med. 2017;74:130-137.

[17] Dumas O, Wiley AS, Quinot C, et al. Occupational exposure to disinfectants and asthma control in US nurses. Eur. Respir. J. 2017;50:pii: 1700237.

[18] Dumas O, Varraso R, Boggs KM, et al. Association of hand and arm disinfection with asthma control in US nurses. Occup. Environ. Med. 2018;75:378-381.

[19] Dumas O, Boggs KM, Quinot C, et al. Occupational exposure to disinfectants and asthma incidence in U.S. nurses: A prospective cohort study. Am. J. Ind. Med. 2020;63:44-50.

[20] Dumas O, Gaskins AJ, Boggs KM, et al. Occupational use of high-level disinfectants and asthma incidence in early to mid-career nurses: a prospective cohort study. Eur. Respir. J. 2019;54:OA3282.

[21] Caridi MN, Humann MJ, Liang X, et al. Occupation and task as risk factors for asthmarelated outcomes among healthcare workers in New York City. Int. J. Hyg. Environ. Health. 2019;222:211-220.

[22] Su FC, Friesen MC, Humann M, et al. Clustering asthma symptoms and cleaning and disinfecting activities and evaluating their associations among healthcare workers. Int. J. Hyg. Environ. Health. 2019;222:873-883. 
[23] Kurth L, Virji MA, Storey E, et al. Current asthma and asthma-like symptoms among workers at a Veterans Administration Medical Center. Int. J. Hyg. Environ. Health. 2017;220:1325-1332.

[24] Patel J, Gimeno Ruiz de Porras D, Mitchell LE, et al. Work-Related Asthma Among Certified Nurse Aides in Texas. Work. Heal. Saf. 2020;68:491-500.

[25] Dumas O, Wiley AS, Henneberger PK, et al. Determinants of disinfectant use among nurses in U.S. healthcare facilities. Am J Ind Med. 2017;60:131-140.

[26] Hawley B, Casey M, Virji MA, et al. Respiratory symptoms in hospital cleaning staff exposed to a product containing hydrogen peroxide, peracetic acid, and acetic acid. Ann. Work Expo. Heal. 2018;62:28-40.

[27] Casey ML, Hawley B, Edwards N, et al. Health problems and disinfectant product exposure among staff at a large multispecialty hospital. Am. J. Infect. Control. 2017;45:1133-1138.

[28] Brooks C, Slater T, Corbin M, et al. Respiratory health in professional cleaners: symptoms, lung function, and risk factors. Clin. Exp. Allergy. 2020;(in press).

[29] Weinmann T, Forster F, Von Mutius E, et al. Association between Occupational Exposure to Disinfectants and Asthma in Young Adults Working in Cleaning or Health Services: Results from a Cross-Sectional Analysis in Germany. J. Occup. Environ. Med. 2019;61:754-759.

[30] Siracusa A, Folletti I, Moscato G. Non-IgE-mediated and irritant-induced work-related rhinitis. Curr. Opin. Allergy Clin. Immunol. 2013;13:159-166.

[31] Mazurek JM, Weissman DN. Occupational Respiratory Allergic Diseases in Healthcare Workers. Curr. Allergy Asthma Rep. 2016;16:77.

[32] Clarhed UKE, Svendsen M, Schiöler L, et al. Chronic Rhinosinusitis Related to Occupational Exposure: The Telemark Population Study. J. Occup. Environ. Med. 2018;60:656-660.

[33] Gonzalez M, Jégu J, Kopferschmitt M-C, et al. Asthma among workers in healthcare settings: role of disinfection with quaternary ammonium compounds. Clin. Exp. Allergy. 2014;44:393-406.

[34] Mirabelli MC, London SJ, Charles LE, et al. Occupation and three-year incidence of respiratory symptoms and lung function decline: the ARIC Study. Respir. Res. 2012;13:24.

[35] Svanes $\varnothing$, Skorge TD, Johannessen A, et al. Respiratory Health in Cleaners in Northern Europe: Is Susceptibility Established in Early Life? PLoS One. 2015;10:e0131959.

[36] Van den Borre L, Deboosere P. Health risks in the cleaning industry: a Belgian census-linked mortality study (1991-2011). Int. Arch. Occup. Environ. Health. 2018;91:13-21.

[37] Kim V, Wang W, Mannino D, et al. Association of birthplace and occupational exposures with chronic bronchitis in US Hispanics/Latinos, 2008-2011. Occup. Environ. Med. 2020;77:344-350.

[38] De Matteis S, Jarvis D, Hutchings $S$, et al. Occupations associated with COPD risk in the large population-based UK Biobank cohort study. Occup. Environ. Med. 2016;73:378-384.

[39] De Matteis S, Jarvis D, Darnton A, et al. The occupations at increased risk of COPD: analysis of lifetime job-histories in the population-based UK Biobank Cohort. Eur. Respir. J. 2019;54:1900186.

[40] Doney B, Hnizdo E, Syamlal G, et al. Prevalence of Chronic Obstructive Pulmonary Disease Among US Working Adults Aged 40 to 70 Years. J. Occup. Environ. Med. 2014;56:1088-1093.

[41] Svanes $\varnothing$, Bertelsen RJ, Lygre S, et al. Cleaning at Home and at Work in Relation to Lung Function Decline and Airway Obstruction. Am J Respir Crit Care Med. 2018;197:1157-1163.

[42] Cummings KJ, Virji MA. The Long-Term Effects of Cleaning on the Lungs. Am. J. Respir. Crit. Care Med. 2018;197:1099-1101. 
[43] Le Moual N, Orlowski E, Schenker MB, et al. Occupational exposures estimated by means of job exposure matrices in relation to lung function in the PAARC survey. Occup Env. Med. 1995;52:634-643.

[44] Dumas O, Le Moual N. Do chronic workplace irritant exposures cause asthma? Curr. Opin. Allergy Clin. Immunol. 2016;16:75-85.

[45] Dumas O, Laurent E, Bousquet J, et al. Occupational irritants and asthma: An Estonian cross-sectional study of 34000 adults. Eur. Respir. J. 2014;44:647-656.

[46] Casas L, Nemery B. Irritants and asthma. Eur. Respir. J. 2014;44:562-564.

[47] Casimirri E, Stendardo M, Bonci M, et al. Biomarkers of oxidative-stress and inflammation in exhaled breath condensate from hospital cleaners. Biomarkers. 2016;21:115-122.

[48] Van Den Broucke S, Pollaris L, Vande Velde G, et al. Irritant-induced asthma to hypochlorite in mice due to impairment of the airway barrier. Arch. Toxicol. 2018;92:1551-1561.

[49] McGovern TK, Goldberger M, Allard B, et al. Neutrophils mediate airway hyperresponsiveness after chlorine-induced airway injury in the mouse. Am. J. Respir. Cell Mol. Biol. 2015;52:513-522.

[50] Reilly MJ, Wang L, Rosenman KD. The Burden of Work-related Asthma in Michigan, 1988-2018. Ann. Am. Thorac. Soc. 2020;17:284-292.

[51] Vandenplas O, Wiszniewska M, Raulf M, et al. EAACI position paper: Irritant-induced asthma. Allergy. 2014;69:1141-1153.

[52] Wang TN, Lin MC, Wu CC, et al. Risks of exposure to occupational asthmogens in atopic and nonatopic asthma: a case-control study in Taiwan. Am J Respir Crit Care Med. 2010;182:1369-1376.

[53] Lillienberg L, Andersson E, Janson C, et al. Occupational Exposure and New-onset Asthma in a Population-based Study in Northern Europe (RHINE). Ann Occup Hyg. 2013;57:482-492.

[54] Dumas O, Siroux V, Luu F, et al. Cleaning and asthma characteristics in women. Am J Ind Med. 2014;57:303-311.

[55] Van Den Broucke S, Vanoirbeek J, Alfaro-Moreno E, et al. Contribution of mast cells in irritant-induced airway epithelial barrier impairment in vitro. Toxicol. Ind. Health. 2020;48233720948771.

[56] Wang M, Tan G, Eljaszewicz A, et al. Laundry detergents and detergent residue after rinsing directly disrupt tight junction barrier integrity in human bronchial epithelial cells. J. Allergy Clin. Immunol. 2019;143:1892-1903.

[57] de Genaro IS, de Almeida FM, Hizume-Kunzler DC, et al. Low dose of chlorine exposure exacerbates nasal and pulmonary allergic inflammation in mice. Sci. Rep. 2018;8:1-13.

[58] Shim JS, Lee HS, Park DE, et al. Aggravation of asthmatic inflammation by chlorine exposure via innate lymphoid cells and CD11cintermediate macrophages. Allergy. 2020;75:381-391.

[59] Tarlo SM, Lemiere C. Occupational asthma. N. Engl. J. Med. 2014;370:640-649.

[60] Tun MH, Tun HM, Mahoney JJ, et al. Postnatal exposure to household disinfectants, infant gut microbiota and subsequent risk of overweight in children. CMAJ. 2018;190:E1097-E1107.

[61] Velazquez S, Griffiths W, Dietz L, et al. From one species to another: A review on the interaction between chemistry and microbiology in relation to cleaning in the built environment. Indoor Air. 2019;29:880-894.

[62] Lai PS, Christiani DC. Impact of occupational exposure on human microbiota. Curr. Opin. Allergy Clin. Immunol. 2019;19:86-91.

[63] Niu Y, Chen R, Wang C, et al. Ozone exposure leads to changes in airway permeability, microbiota and metabolome: a randomised, double-blind, crossover trial. Eur. Respir. J. 2020;56.

[64] Goodyear N, Markkanen P, Beato-Melendez C, et al. Cleaning and disinfection in home care: A comparison of 2 commercial products with potentially different 
consequences for respiratory health. Am. J. Infect. Control. 2018;46:410-416.

[65] Quinot C, Amsellem-Dubourget S, Temam S, et al. Development of a bar code-based exposure assessment method to evaluate occupational exposure to disinfectants and cleaning products: A pilot study. Occup. Environ. Med. 2018;75:668-674.

[66] Marbac M, Sedki M, Boutron-Ruault MC, et al. Patterns of cleaning product exposures using a novel clustering approach for data with correlated variables. Ann. Epidemiol. 2018;28:563-569.e6.

[67] Lovén K, Isaxon C, Wierzbicka A, et al. Characterization of airborne particles from cleaning sprays and their corresponding respiratory deposition fractions. J. Occup. Environ. Hyg. 2019;16:656-667.

[68] Su FC, Friesen MC, Stefaniak AB, et al. Exposures to volatile organic compounds among healthcare workers: Modeling the effects of cleaning tasks and product use. Ann. Work Expo. Heal. 2018;62:852-870.

[69] Benjamin ML, Arnold S, Rao M, et al. Ventilation and posture effects on inhalation exposures to volatile cleaning ingredients in a simulated domestic worker cleaning environment. Indoor Air. 2020;(in press).

[70] Lin N, Rosemberg M-A, Li W, et al. Occupational exposure and health risks of volatile organic compounds of hotel housekeepers: Field measurements of exposure and health risks. Indoor Air. 2020;(in press). 


\begin{tabular}{|c|c|c|c|c|}
\hline Reference & Study design, country, year & Outcome & Exposure & Main results \\
\hline $\begin{array}{l}\text { Kurth et al., } 2017 \\
\text { [23] }\end{array}$ & $\begin{array}{l}\text { USA, } 2012-2014, \text { cross-sectional } \\
\text { study, healthcare workers (mean age: } \\
47 \text { years), } n=247\end{array}$ & $\begin{array}{l}\text { Current } \\
\text { asthma }\end{array}$ & $\begin{array}{l}\text { Exposure to cleaning tasks } \\
\text { and products evaluated by } \\
\text { questionnaire }\end{array}$ & $\begin{array}{l}\text { Tasks of cleaning equipment and environmental surfaces (unadjusted PR 1.70, } \\
95 \% \mathrm{Cl} 1.07-2.71) \text { and floor cleaning and maintenance }(1.88,1.10-3.22) \text { had } \\
\text { significantly higher prevalence of current asthma. }\end{array}$ \\
\hline $\begin{array}{l}\text { Casey et al., } 2017 \\
{[27] ; \text { Hawley et al. }} \\
2018[26]\end{array}$ & $\begin{array}{l}\text { USA, } 2015 \text {, cross-sectional study } \\
\text { (health hazard evaluation), hospital } \\
\text { workers (median age: } 43), n=163\end{array}$ & $\begin{array}{l}\text { Current } \\
\text { asthma }\end{array}$ & $\begin{array}{l}\text { Air samples measurements } \\
\text { for hydrogen peroxide, } \\
\text { peracetic acid, and acetic } \\
\text { acid. }\end{array}$ & $\begin{array}{l}\text { Workers in the department with the highest air measurements had higher risk of } \\
\text { current asthma (SMR } 3.47 ; 95 \% \mathrm{Cl}[1.48-8.13]) \text { compared with the U.S. } \\
\text { population. In a smaller sub-sample }(n=50) \text { who completed a post-shift survey, } \\
\text { increased exposure was associated with acute nasal and eye irritation but not } \\
\text { significantly with lower airway symptoms. }\end{array}$ \\
\hline $\begin{array}{l}\text { Dumas et al., } \\
2017 \text { [17]; Dumas } \\
\text { et al., } 2018 \text { [18] }\end{array}$ & $\begin{array}{l}\text { USA, } 2014-2015 \text {, cross-sectional } \\
\text { study, female registered nurses with } \\
\text { asthma (mean age: } 58 \text { years), } n=4102\end{array}$ & $\begin{array}{l}\text { Asthma } \\
\text { control, } \\
\text { evaluated by } \\
\text { the Asthma } \\
\text { Control Test }\end{array}$ & $\begin{array}{l}\text { Current exposure to } \\
\text { cleaning products / } \\
\text { disinfectants evaluated by } \\
\text { questionnaire and a JTEM }\end{array}$ & $\begin{array}{l}\text { Products used to clean surface/instruments: weekly self-reported use of } \\
\text { disinfectants to clean medical instruments associated with poorly (OR } 1.37 \text {; } \\
95 \% \mathrm{Cl} 1.05-1.79 \text { ) and very poorly (1.88; } 1.38-2.56 \text { ) controlled asthma (P-trend } \\
0.004 \text { ). Using the JTEM, high levels of exposure to formaldehyde, } \\
\text { glutaraldehyde, hypochlorite bleach, hydrogen peroxide and enzymatic cleaners } \\
\text { were associated with poor asthma control (all P-trend<0.05). } \\
\text { Hand/arm hygiene tasks: dose-response relationship between frequency of arm } \\
\text { hygiene tasks (never to }>10 \text { times/day) and poor asthma control. }\end{array}$ \\
\hline $\begin{array}{l}\text { Caridi et al., } 2019 \\
\text { [21]; Su et al., } \\
2019 \text { [22] }\end{array}$ & $\begin{array}{l}\text { USA, 2014, cross-sectional study, } \\
\text { healthcare workers (mean age: } 49 \\
\text { years), } n=2030\end{array}$ & $\begin{array}{l}\text { Current } \\
\text { asthma; } \\
\text { Asthma health } \\
\text { clusters } \\
\text { identified by } \\
\text { hierarchical } \\
\text { clustering }\end{array}$ & $\begin{array}{l}\text { Exposure to cleaning } \\
\text { products / disinfectants } \\
\text { evaluated by questionnaire } \\
\text { and exposure clusters } \\
\text { identified by hierarchical } \\
\text { clustering }\end{array}$ & $\begin{array}{l}\text { Tasks: cleaning fixed surface associated with increased risk of current asthma; } \\
\text { Chemical exposures: alcohols associated with "mild asthma symptoms" and } \\
\text { "asthma attacks/ exacerbations". Bleach associated with "mild asthma } \\
\text { symptoms", "undiagnosed/ untreated asthma", and "asthma } \\
\text { attacks/exacerbations". Enzymes associated with "undiagnosed/untreated } \\
\text { asthma" and "asthma attacks/ exacerbations". } \\
\text { Exposure clusters: "housekeeping/chlorine" associated with } \\
\text { "undiagnosed/untreated asthma" (OR } 3.11 ; 95 \% \mathrm{Cl} 1.46-6.63) \text { and "asthma } \\
\text { attacks/exacerbations" (2.71; } 1.25-5.86) \text {. "General cleaning/laboratory" } \\
\text { associated with "asthma attacks/exacerbations" (2.35; } 1.07-5.13) \text {. "Disinfection } \\
\text { products" associated with "mild asthma symptoms" (1.81; 1.09-2.99) and } \\
\text { "undiagnosed/untreated asthma" (3.42; 1.24-9.39). }\end{array}$ \\
\hline $\begin{array}{l}\text { Weinmann et al., } \\
2019[29]\end{array}$ & $\begin{array}{l}\text { Germany, cross-sectional study, } \\
\text { workers in cleaning or health service } \\
\text { (aged } 20-24 \text { years), } n=265\end{array}$ & $\begin{array}{l}\text { Doctor- } \\
\text { diagnosed } \\
\text { asthma }\end{array}$ & $\begin{array}{l}\text { Exposure to disinfectants } \\
\text { evaluated by questionnaire }\end{array}$ & $\begin{array}{l}\text { Exposure to disinfectants for more than twelve months associated with doctor- } \\
\text { diagnosed asthma (OR: } 2.99,95 \% \mathrm{Cl}: 1.36-6.55) \text {. }\end{array}$ \\
\hline $\begin{array}{l}\text { Dumas et al., } \\
2020[19]\end{array}$ & $\begin{array}{l}\text { USA, } 2009 \text {, prospective cohort study } \\
\text { ( } \sim 6-\text { ear follow-up), female registered } \\
\text { nurses (mean age: } 55 \text { years), } \\
\mathrm{n}=61,538\end{array}$ & $\begin{array}{l}\text { Asthma } \\
\text { incidence }\end{array}$ & $\begin{array}{l}\text { Current exposure to } \\
\text { cleaning products / } \\
\text { disinfectants evaluated by } \\
\text { questionnaire and a JTEM }\end{array}$ & $\begin{array}{l}\text { Weekly use of disinfectants to clean surfaces only or to clean medical } \\
\text { instruments was not associated with incident asthma (surfaces: HR } 1.12,95 \% \mathrm{Cl} \\
0.87-1.43 \text {; instruments: } 1.13,0.87-1.48 \text { ). No association was observed between } \\
\text { exposure to specific products evaluated by the JTEM and asthma incidence }\end{array}$ \\
\hline $\begin{array}{l}\text { Dumas et al., } \\
2020[20]\end{array}$ & $\begin{array}{l}\text { USA \& Canada, 2010-2018, } \\
\text { prospective cohort study ( } \sim \text {-year } \\
\text { follow-up), female nurses (mean age: } \\
34 \text { years), } n=17,280\end{array}$ & $\begin{array}{l}\text { Asthma } \\
\text { incidence }\end{array}$ & $\begin{array}{l}\text { Duration of exposure to high } \\
\text { level disinfectants evaluated } \\
\text { by questionnaire }\end{array}$ & $\begin{array}{l}\text { Nurses who reported }>5 \text { years of use of high level disinfectants (11\%) had } \\
\text { increased risk of incident asthma (HR } 1.38,95 \% \mathrm{Cl} 1.03-1.85)\end{array}$ \\
\hline $\begin{array}{l}\text { Brooks et al., } \\
2020[28]\end{array}$ & $\begin{array}{l}\text { New Zealand, } 2008-2010, \text { cross- } \\
\text { sectional study, } 425 \text { cleaners (mean } \\
\text { age: } 45 \text { years) and } 281 \text { reference } \\
\text { workers (mean age: } 40 \text { years) }\end{array}$ & $\begin{array}{l}\text { Current } \\
\text { asthma }\end{array}$ & $\begin{array}{l}\text { Exposure to cleaning tasks } \\
\text { and products evaluated by } \\
\text { questionnaire }\end{array}$ & $\begin{array}{l}\text { Cleaners had increased risk of current asthma. Bleach (OR } 1.87 ; 95 \% \mathrm{Cl} 1.12- \\
\text { 3.14) and decalcifiers (2.77; } 1.11-6.92) \text { associated with current asthma, } \\
\text { compared to reference workers }\end{array}$ \\
\hline $\begin{array}{l}\text { Patel et al., } 2020 \\
\text { [24] }\end{array}$ & $\begin{array}{l}\text { USA, } 2016-2017, \text { cross-sectional } \\
\text { study, certified nurse aides (mean age } \\
38 \text { years), } n=239\end{array}$ & $\begin{array}{l}\text { New-onset } \\
\text { asthma, }\end{array}$ & $\begin{array}{l}\text { Exposure to cleaning } \\
\text { products / disinfectants } \\
\text { during the longest held job, }\end{array}$ & $\begin{array}{l}\text { New-onset asthma not analyzed because of low number of cases }(n=11) \text {. No } \\
\text { significant association between cleaning/disinfections tasks and products and } \\
\text { BHR-related symptoms. Highest OR observed for patient care cleaning and }\end{array}$ \\
\hline
\end{tabular}




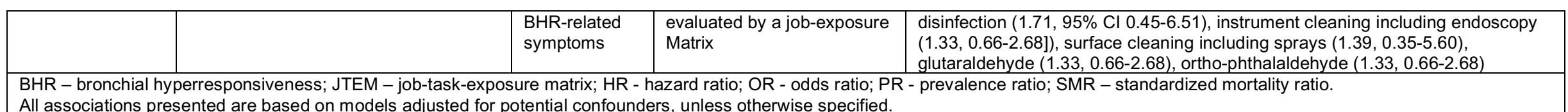




\begin{tabular}{|c|c|c|c|c|}
\hline Reference & Study design, country, year & Outcome & Exposure & Main results \\
\hline $\begin{array}{l}\text { Van den Borre L } \\
\text { et al. } 2018 \text { [36] }\end{array}$ & $\begin{array}{l}\text { Belgium, 1991-2011, mortality } \\
\text { study (census, register and death } \\
\text { certificate data), } n=260,931 \text { deaths }\end{array}$ & $\begin{array}{l}\text { Cause specific mortality } \\
\text { in death certificate (ICD } \\
9 / 10)\end{array}$ & $\begin{array}{l}\text { Current job in } 1991 \\
\text { (cleaners vs. non-manual } \\
\text { workers) }\end{array}$ & $\begin{array}{l}\text { SMRs for all-cause mortality (men: SMR } 1.25,95 \% \mathrm{Cl} 1.22-1.28 \text {; women: } \\
1.10,1.07-1.13 \text { ) and for COPD mortality (men: } 2.13,1.92-2.37 \text {; women } 2.03 \text {, } \\
1.77-2.31 \text { ) were higher among cleaners than among non-manual workers }\end{array}$ \\
\hline $\begin{array}{l}\text { Svanes et al. } \\
2018 \text { [41] }\end{array}$ & $\begin{array}{l}\text { Europe, } 1992-94,1998-02 \text {, and } \\
2010-12 \text {, prospective cohort study, } \\
\text { population-based sample, } n=6,235 \\
\text { adults (mean age: } 54 \text { at end of } \\
\text { follow-up) }\end{array}$ & $\begin{array}{l}\text { Decline in FEV } \mathrm{F}_{1}, \mathrm{FVC} \text {, } \\
\text { FEV } / \text { FVC; Incidence of } \\
\text { airway obstruction (post- } \\
\text { bronchodilator } \\
\mathrm{FEV}_{1} / \mathrm{FVC}<\mathrm{LLN} \text { ) }\end{array}$ & $\begin{array}{l}\text { Cleaning exposures } \\
\text { evaluated by } \\
\text { questionnaire: cleaning at } \\
\text { home, working as cleaner }\end{array}$ & $\begin{array}{l}\text { Cleaning activities (both cleaning at home and working as cleaner) } \\
\text { associated with accelerated FEV1 and FVC decline in women only. Results } \\
\text { were similar in participants without asthma. No association between } \\
\text { cleaning activities and FEV1/FVC decline or airway obstruction. }\end{array}$ \\
\hline $\begin{array}{l}\text { De Matteis et al. } \\
2016 \text { [38]; De } \\
\text { Matteis et al., } \\
2019 \text { [39] }\end{array}$ & $\begin{array}{l}\text { UK, } 2006-2010 \text {, cross-sectional } \\
\text { study, population-based sample, } \\
\mathrm{n}=228,614 \text { adults currently } \\
\text { working (mean age: } 52 \text { ) } / \mathrm{n}= \\
94,551 \text { adults with complete job } \\
\text { histories (mean age: } 56 \text { years) }\end{array}$ & $\begin{array}{l}\text { COPD cases identified } \\
\text { by pre-bronchodilator } \\
\text { FEV } 1 / F V C<L L N\end{array}$ & Current job / job history & $\begin{array}{l}\text { Currently working as domestic cleaner (PR } 1.43,95 \% \mathrm{Cl}: 1.28-1.59) \text { or } \\
\text { industrial cleaner ( } 1.96,1.16-3.31 \text { ) was associated with increased risk of } \\
\text { COPD. Results were similar in never-smokers and participants without } \\
\text { asthma. Ever working as a cleaner or duration of cleaning employment was } \\
\text { not associated with COPD. }\end{array}$ \\
\hline $\begin{array}{l}\text { Dumas et al., } \\
2019[9]\end{array}$ & $\begin{array}{l}\text { USA, 2009, prospective cohort } \\
\text { study (6-year follow-up), female } \\
\text { registered nurses (mean age: } 55 \\
\text { years), } n=73,262\end{array}$ & $\begin{array}{l}\text { COPD incidence, } \\
\text { evaluated by } \\
\text { questionnaire }\end{array}$ & $\begin{array}{l}\text { Current exposure to } \\
\text { cleaning products / } \\
\text { disinfectants evaluated by } \\
\text { questionnaire and a JTEM }\end{array}$ & $\begin{array}{l}\text { Weekly use of disinfectants to clean surfaces only and to clean medical } \\
\text { instruments was associated with incident COPD (surfaces: HR } 1.38,95 \% \mathrm{Cl} \\
1.13-1.68 \text {; instruments: } 1.31,1.07-1.61 \text { ). Using the JTEM, high-level } \\
\text { exposure to glutaraldehyde, bleach, hydrogen peroxide, alcohol, and } \\
\text { quaternary ammonium compounds was significantly associated with COPD } \\
\text { incidence }\end{array}$ \\
\hline $\begin{array}{l}\text { Brooks et al., } \\
2020[28]\end{array}$ & $\begin{array}{l}\text { New Zealand, } 2008-2010, \text { cross- } \\
\text { sectional study, } 425 \text { cleaners } \\
\text { (mean age: } 45 \text { years) and } 281 \\
\text { reference workers (mean age: } 40 \\
\text { years) }\end{array}$ & Lung function & $\begin{array}{l}\text { Exposure to cleaning } \\
\text { tasks and products } \\
\text { evaluated by } \\
\text { questionnaire }\end{array}$ & $\begin{array}{l}\text { Cleaners had lower lung function (FEV1, FVC) than reference workers; use } \\
\text { of bleach and specific sprays among cleaners associated with lower FEV1 } \\
\% \text { predicted, compared to reference workers. }\end{array}$ \\
\hline $\begin{array}{l}\text { Kim et al., } 2020 \\
{[37]}\end{array}$ & $\begin{array}{l}\text { USA, 2008-2011, cross-sectional } \\
\text { study, Hispanic adults, } n=13,259\end{array}$ & $\begin{array}{l}\text { Chronic bronchitis } \\
\text { evaluated by } \\
\text { questionnaire }\end{array}$ & $\begin{array}{l}\text { Current exposure to } \\
\text { various agents, including } \\
\text { cleaning and disinfecting } \\
\text { solutions, evaluated by } \\
\text { questionnaire }\end{array}$ & $\begin{array}{l}\text { Participants exposed to cleaning or disinfecting solutions had a higher } \\
\text { adjusted prevalence of CB than those not exposed }(12.6 \%(9.1-17.1) \text { vs } \\
11.8 \%(9.2-15.1) ; p=0.024) \text {. }\end{array}$ \\
\hline
\end{tabular}

